\title{
АЛЮМОФТОРИДНАЯ И АЛЮМОФОСФАТНАЯ МИНЕРАЛИЗАЦИЯ ЖАРЧИХИНСКОГО МОЛИБДЕНОВОГО МЕСТОРОЖДЕНИЯ (ЗАПАДНОЕ ЗАБАЙКАЛЬЕ)
}

\author{
А. А. Савченко, Г. С. РипI \\ Геологический институт СО РАН
}

Поступила в редакцию 20 ноября 2017 г.

\begin{abstract}
Аннотация: в статье представлена характеристика минеральных парагенезисов, присутствующиих в породах и рудах Жарчихинского молибденового месторождения. Особенностью месторождения является наличие в пределах его, кроме молибденитовой, также фтор-бериллиевой, алюмофторидной и алюмофосфатной минеральных ассоциаций. Такие парагенезисы не характерны для молибденовых месторождений и предполагают отсутствие между ними генетической связи. В составе алюмофторидной минерализации присутствуют: прозопит, ральстонит, геарксутит, жарчихит, черчит и фторсодержащий (до 6,23 мас. \%) минерал группь плюмбогуммита с промежуточным составом гояџит-горсейксит-флоренсит. Так же здесь обнаружень накрит и каолинит. Пространственно разобщенная от молибденитовой, фтор-бериллиевая минерализация представлена фенакитом и бертрандитом ассоциирующими с флюоритом, кварием и калиевым полевым шиатом.
\end{abstract}

Ключевые слова: молибденовое месторождение, алюмофторид, прозопит, ральстонит, алюмофосфат, фтор-бериллиевая минерализация,

\section{MINERAL COMPOSITION \\ OF THE ZHARCHIKHA MOLYBDENUM DEPOSIT (WESTERN TRANSBAIKALIA)}

\begin{abstract}
Zharkhikha molybdenum deposit. A special feature of the deposit is a presence of fluoro-beryllium, aluminumfluoride and aluminophosphate associations as well as molybdenite. These parageneses are not typical for molybdenum deposits and assume the absence of a genetic connection between them. The aluminofluoride paregenesis includes prozopite, ralstonite, reductuite, zarcinite, scales and F-bearing mineral (up to $6.23 \mathrm{wt} \%$ ) of the plumgumimite group with an intermediate composition of goyazite-gorceixite-florencite. In addition, there are nakrit and kaolinite. Fluor-beryllium mineralization is spatially separated from molybdenite mineralization and is represented by phenacite and bertrandite with fluorite, quartz and feldspar.

Key words: molybdenum deposit, aluminumfluoride, prosopite, ralstonite aluminophosphate, fluor-beryllium mineralization
\end{abstract}

\section{Введение}

Одной из особенностей Жарчихинского месторождения является присутствие на его площади флюорит-бертрандит-фенакитовой и алюмофторидной с алюмофосфатами минерализаций. Алюмофторидная минерализация не установлена ни на одном из многих десятков проявлений и месторождений Западного Забайкалья $[1,2]$. Она не характерна и для молибденовых месторождений других регионов [3, 4], связанных с гранитами, и в основном встречается в зонах гидротермального изменения [5]. Более типична она для щелочных комплексов пород. На Жарчихинском месторождении присутствуют дайки щелочных сиенитов и кварцевые прожилки, содержащие в своем составе щелочные амфиболы. Необходимым представляется решение проблемы связи алюмофторидной минерализации с этим типом магматических пород. Аналогичная проблема стоит и с фтор-бериллиевой минерализацией. Месторождение расположено в границах бериллиеносной провинции $[6,7]$ с типичной для нее флюорит-бертрандит-фенакитовой минерализацией. Для решения этих проблем были проведены детальные минералогические исследования.

\section{Методы исследований}

Состав минералов определен на модернизированном рентгеновском микроанализаторе MAР-3 (Канакин С. В.). Съемки проводились при 15-20 kV, ускоряющем напряжении тока зонда от 20 до 40 нА, времени измерения 20 сек и диаметре зонда 2-3 мкм. Для учета тормозной составляющей фона минералов, содер- 
жащих редкоземельные элементы, применен расчетный способ, при котором интенсивности фона на образце получаются посредством пересчета интенсивности, измеренной на «фоновом стандарте» без отстройки спектрометров с аналитической линии [8]. Он позволяет исключить ошибки, возникающие в тех случаях, когда учет наложений производится до или после расчета поправок на матричные эффекты.
Микроструктурные особенности, взаимоотношения и однородность минералов изучались на электронном микроскопе LEO-1430 с энергодисперсионным спектрометром Inca Energy-300 (Ходырева Е. В.) в ГИН СО РАН.

При написании статьи нами были использованы результаты поисково-разведочных работ $[9,10]$ и материалы из публикаций сотрудников ВИМСа $[1,11,12]$.
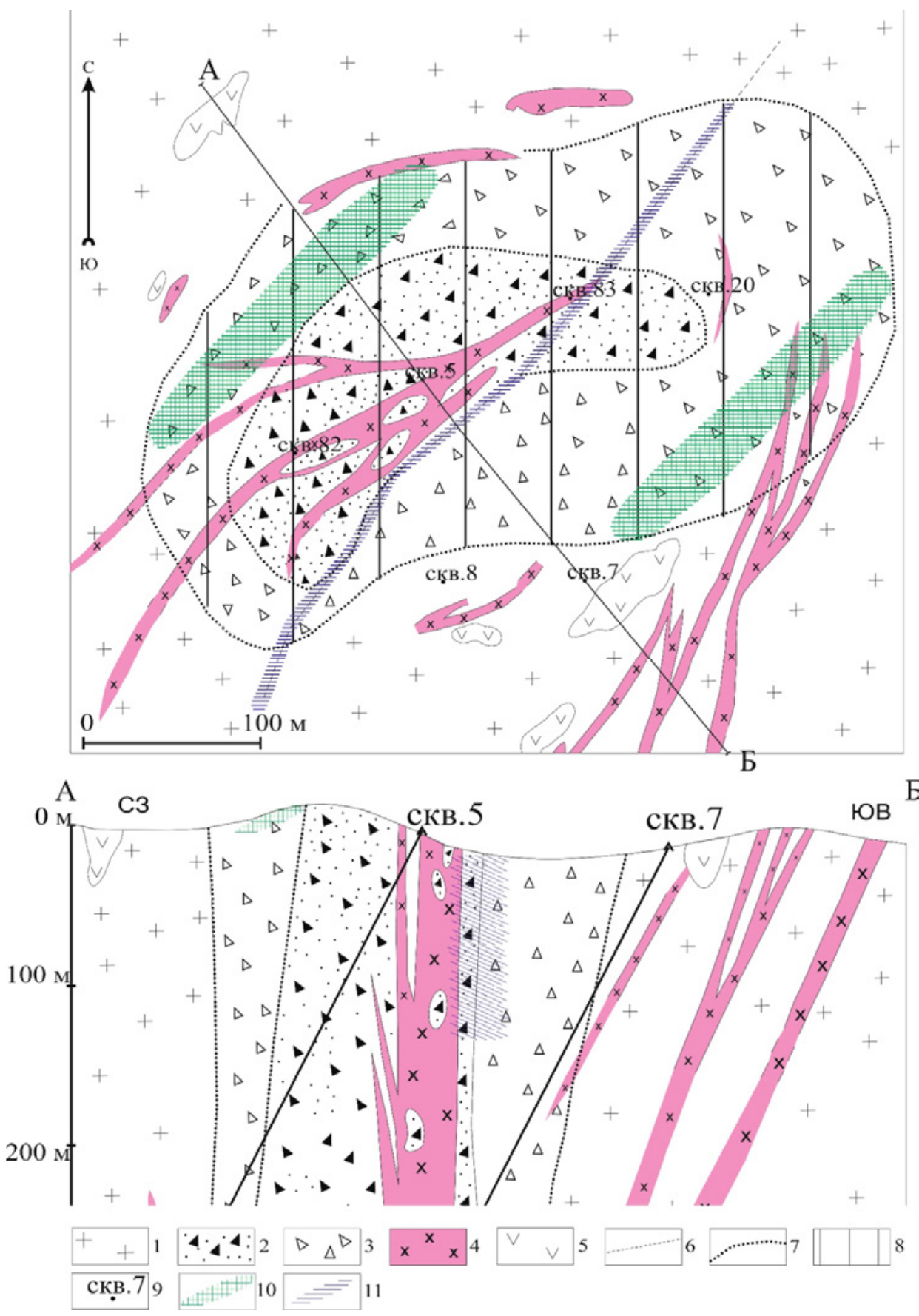

Puc. 1. Схема геологического строения и разрез Жарчихинского месторождения по [9] : 1 -гранитоиды; 2 - внутреняя зона брекчий (граниты, сиениты, микродиориты, трахиты); 3 - внешняя зона брекчий (граниты, сиениты); 4 - дайки гранитов; 5 ксенолиты монцонитов и диоритов; 6 -линия тектонического нарушения; 7 - границы распространения брекчий; 8 - поле распространения молибденовой минерализации; 9 - номера скважин; 10 - распространение фтор-бериллиевой минерализации; 11-распространение алюмофторидной минерализации. 


\section{Геологическое строение месторождения}

Жарчихинское месторождение молибдена находится в центральном районе Бурятии (40 км от г. Улан-Удэ), вблизи железной дороги и в 5 км от р. Селенги. Оно изучено на стадии предварительной разведки. Помимо Жарчихинского месторождения на прилегающей территории известно еще несколько рудопроявлений молибдена (Колобковское, Куналейское, Хардебанское, Надеинское, Право-Куйтунское и др.), свидетельствующие о специализации района на этот тип полезного ископаемого.

Информация по геологическому строению и вещественному составу руд месторождения приведена в небольшом числе публикаций [1, 2, 9,11-13]. В них представлены, помимо данных о геологическом строении, сведения о последовательности формирования и составе минеральных парагенезисов.

Рудное поле сложено крупно- и среднезернистыми лейкократовыми гранитами, сиенитами и граносиенитами позднепалеозойского (280 млн лет) возраста $[10,11,13]$. Перечисленные породы присутствуют в составе крупного плутона и имеют между собой постепенные переходы. Они содержат ксенолиты монцонитов, диоритов и монцодиоритов. В центральной части рудного поля гранитоиды брекчированы и прорваны дайками трахитовых и трахириолитовых порфиров, граносиенит-порфиров и мелкозернистых гранитов (рис. 1). Гранитоиды относятся к породам умеренно-щелочного ряда с калиево-натриевым типом щелочности [10].

Месторождение представлено почти вертикальным столбообразным телом минерализованных брекчий, представленных гранитами, сиенитами, микродиоритами и трахитами, и практически совпадает с границами их распространения, Штокверк размером $750 \times 250$ м в плане разведан на глубину 500-550 м, а двумя скважинами прослежен до глубины 800 м.

На месторождении установлено более 50 минеральных видов, сформировавшихся в несколько стадий. Большая часть из них представлена редкой вкрапленностью. Среди жильных минералов преобладают полевые шпаты и кварц. Относительно часто встречаемые минералы приведены в таблице 1.

Минеральный состав руд

\begin{tabular}{|c|c|c|}
\hline Рудные & Нерудные & Гипергенные \\
\hline молибденит & кварц & ферримолибдит \\
\hline пирит & микроклин & повеллит \\
\hline сфалерит & $\begin{array}{c}\text { кислый } \\
\text { плагиоклаз }\end{array}$ & гётит \\
\hline галенит & флюорит & ярозит \\
\hline халькопирит & сидерит & англезит \\
\hline пирротин & кальцит & смитсонит \\
\hline марказит & анкерит & церуссит \\
\hline магнетит & мусковит & гидрооксилы \\
марганца \\
\hline гематит & барит & \\
\hline \multicolumn{2}{|c}{} \\
\hline
\end{tabular}

Рудная минерализация образует рассеянную вкрапленность, сгустки агрегатных скоплений в интенсивно дробленых породах и прожилки молибденитового, кварц-молибденитового состава, которые являются главными рудными компонентами штокверка. Минерализация продуктивного этапа сформировалась при температурах $275-380^{\circ} \mathrm{C}$ [1]. Позднее образовались пиритовые, кварц-пирит-флюоритовые и кварцфлюорит-пирит-полиметаллические прожилки. Кроме того, на площади месторождения распространены безрудные существенно кварцевые с арфведсонитом и мусковитом минеральные ассоциации.

Количественные соотношения минералов в рудах по данным технологических исследований представлены в таблице 2.

Таблица 2

Соотношение наиболее распространённых минералов в рудах (об. \%)

\begin{tabular}{|l|l|}
\hline \multicolumn{1}{|c|}{ Рудные } & \multicolumn{1}{c|}{ Нерудные } \\
\hline молибденит 0,16 & кварц 13,0 \\
\hline пирит 1,5 & полевые шпаты 75,3 \\
\hline гидрооксиды железа 3,4 & карбонаты, флюорит 1,6 \\
\hline $\begin{array}{l}\text { сфалерит, галенит, } \\
\text { халькопирит } 0,018\end{array}$ & биотит, мусковит 5,0 \\
\hline
\end{tabular}

Кроме того, в акцессорных количествах в составе протолочек обнаружены висмутовый минерал, шеелит, турмалин, берилл, фенакит, вольфрамит, арсенопирит.

Вдоль зон дробления фиксируется аргиллизация пород, сопровождающая кварцевые и кварцалюмофторидные прожилки с сидеритом, каолинитом и сульфидами (галенитом, пиритом, сфалеритом). Наиболее интенсивно эти процессы захватили породы вдоль осевой зоны разлома в центральной части месторождения (рис. 1). Прожилки образовались при температурах $100-170^{\circ} \mathrm{C}[1]$.

\section{Последовательность формирования месторождения}

Минеральные парагенезисы на месторождении сформированы в три этапа (табл. 3).

На раннем этапе образовалась флюоритбериллиевая ассоциация. В этот же этап сформировались кварцевые и кварц-полевошпатовые прожилки. Рудный этап сопровождался образованием молибденитовых, кварц-молибденитовых прожилков в ассоциации с бедной вкрапленностью пирита и флюорита. На завершающем этапе сформировалась алюмофторидная минерализация с сульфидами железа, свинца и цинка. Рудогенез завершился образованием карбонатных (кальцитовых) и кварц-карбонатных прожилков. Неясным осталось время кристаллизации кварцевых прожилков со щелочным амфиболом.

\section{Дорудный этап}

Флюорит-квария-полевошпатовые прожилки с бериллийсодержащими минералами встречаются в гранитах и сиенитах периферических частей месторождения. Они обнаружены также в центральной брекчии. Это 
Алюмофторидная и алюмофосфатная минерализачия Жарчихинского молибденового месторождения...

Таблица 3

Последовательность формирования минеральных ассоциащий

Жарчихинского месторождения и метасоматические проиессы их сопровождающие

\begin{tabular}{|c|c|c|}
\hline Последовательность образования & Ассоциации минералов & Метасоматические процессы \\
\hline Дорудный & $\begin{array}{c}\text { Кварц-микроклин-флюорит- } \\
\text { бертрандит-фенакитовая }\end{array}$ & $\begin{array}{c}\text { Калишпатизация } \\
\text { Альбитизация } \\
\text { Флюоритизация }\end{array}$ \\
\hline Рудный & $\begin{array}{c}\text { Кварц-микроклин-флюоритовая } \\
\text { Молибденит-кварцевая } \\
\text { «Сухие» молибденитовые прожилки } \\
\text { Кварц-сульфидная }\end{array}$ & $\begin{array}{l}\text { Окварцевание } \\
\text { Флюоритизация } \\
\text { Пиритизация }\end{array}$ \\
\hline Заключительный & $\begin{array}{c}\text { Алюмофторидная с кварцем, } \\
\text { флюоритом, каолинитом, } \\
\text { карбонатами, баритом, сульфидами } \\
\text { Кварц-карбонатная }\end{array}$ & $\begin{array}{c}\text { Аргиллизация } \\
\text { Карбонатизация }\end{array}$ \\
\hline
\end{tabular}

прожилки и выделения неправильной формы переменной мощности (до 1,5-2 см), ветвящиеся, имеющие неровные границы с вмещающими породами. Нередко они слагают собой цемент в участках дробленых пород. Здесь же встречается редкая вкрапленность пирита, мусковита. Полевые шпаты представлены микроклином и альбитом. Последний развивается по калиевому полевому шпату, иногда нацело замещая его. Среди бериллиевых минералов установлены бертрандит и фенакит. Первый ассоциирует большей частью с флюоритом и калиевым полевымшпатом, второй тяготеет к существенно кварцевым и флюорит-кварцевым выделениям. Формирование этих прожилков происходило при температурах, достигавших $450-490^{\circ} \mathrm{C}[1]$.

Полевошпат-кварцевые и кварцевые прожилки развиты как внутри рудной зоны, так и за ее пределами во вмещающих гранитах и сиенитах. Это суще- ственно мономинеральные кварцевые, реже кварцполевошпатовые парагенезисы иногда с небольшим количеством флюорита. Участками они раздроблены, секутся рудными прожилками. Кварц в них, как правило, крупнозернистый, а распределение полевого шпата (микроклина) и флюорита весьма неравномерное. В некоторых прожилках присутствует арфведсонит (табл. 4 , рис. 2 а-б), слагающий тонкопризматические кристаллы и их агрегатные скопления в кварце. Вместе с амфиболом встречены зерна рутила. В рутиле в пределах 0,5-1,2 мас. \% присутствует $\mathrm{FeO}$, в одной пробе до 1,3 мас. $\% \mathrm{Nb}_{2} \mathrm{O}_{5}$.

В сравнении с эталонным, арфведсонит с месторождения Жарчиха содержит меньшее количество $\mathrm{Na}_{2} \mathrm{O}$, компенсируемое $\mathrm{K}_{2} \mathrm{O}$, и наименьшее $\mathrm{FeO}-$ $\mathrm{TiO}_{2}, \mathrm{MnO}, \mathrm{MgO}$. На классификационной диаграмме амфибол из полевошпат-кварцевых прожилков попадает в поле арфведсонита (рис. 3).

Таблица 4

Химический состав арфведсонита (мас. \%)

\begin{tabular}{|c|c|c|c|c|}
\hline № п/П & 1 & 2 & 3 & 4 \\
\hline $\mathrm{SiO}_{2}$ & 51,07 & 51,07 & 51,34 & 52,01 \\
\hline $\mathrm{TiO}_{2}$ & 0,58 & 0,58 & - & 0,53 \\
\hline $\mathrm{Al}_{2} \mathrm{O}_{3}$ & 0,81 & 1,04 & 0,89 & 0,68 \\
\hline $\mathrm{FeO}$ & 22,36 & 23,22 & 22,89 & 23,2 \\
\hline $\mathrm{MnO}$ & 3,25 & 3,28 & 2,29 & 3,45 \\
\hline $\mathrm{MgO}$ & 7,64 & 7,41 & 7,3 & 7,63 \\
\hline $\mathrm{CaO}$ & 1,61 & 1,39 & 1,9 & 1,33 \\
\hline $\mathrm{Na}_{2} \mathrm{O}$ & 8,1 & 7,94 & 7,98 & 7,98 \\
\hline $\mathrm{K}_{2} \mathrm{O}$ & 1,08 & 1,08 & 1,19 & 1,17 \\
\hline Сумма & 96,52 & 99,09 & 95,78 & 100,31 \\
\hline$-\mathrm{O}=\mathrm{F}$ & - & 0,86 & - & 0,98 \\
\hline \multicolumn{5}{|c|}{ Кристаллохимические формуль рассчитань на 23 атома кислорода } \\
\hline $\mathrm{Si}$ & 7,96 & 7,94 & 8,05 & 8,00 \\
\hline $\mathrm{Ti}$ & 0,07 & 0,07 & - & 0,06 \\
\hline $\mathrm{Al}$ & 0,15 & 0,19 & 0,16 & 0,12 \\
\hline $\mathrm{Fe}$ & 2,91 & 3,02 & 3,00 & 2,98 \\
\hline $\mathrm{Mn}$ & 0,43 & 0,43 & 0,30 & 0,45 \\
\hline $\mathrm{Mg}$ & 1,78 & 1,72 & 1,71 & 1,75 \\
\hline $\mathrm{Ca}$ & 0,27 & 0,23 & 0,32 & 0,22 \\
\hline $\mathrm{Na}$ & 2,45 & 2,39 & 2,43 & 2,38 \\
\hline $\mathrm{K}$ & 0,22 & 0,22 & 0,24 & 0,23 \\
\hline $\mathrm{F}$ & - & 1,02 & - & 1,03 \\
\hline
\end{tabular}

Примечание: Состав минерала приведен без учета воды. Здесь и далее «-» ниже предела обнаружения. 

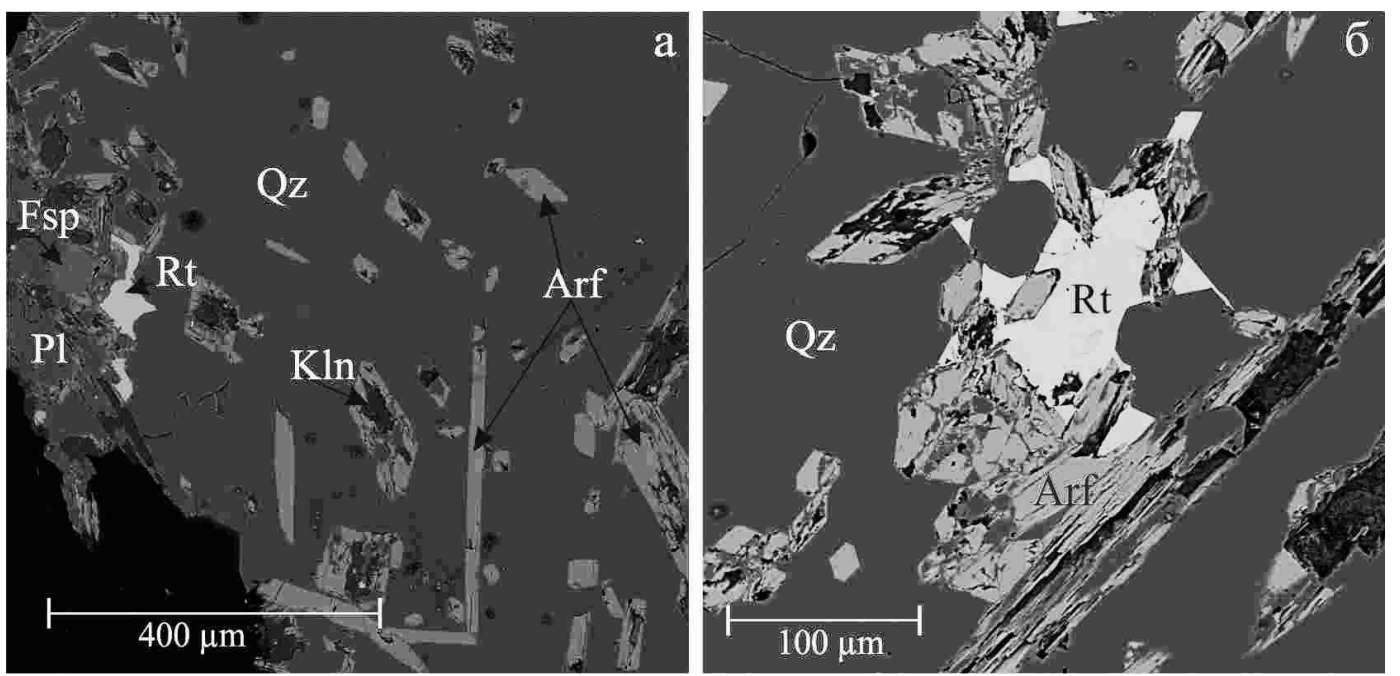

Puc. 2. Арфведсонит и рутил в полевошпат-кварцевых и кварцевых прожилках. Изображения в отраженных электронах. Здесь и далее сокращения: кварц - Qz, калиевый полевой шпат - Fsp, плагиоклаз - Pl, каолинит - Kln, pyтил - Rt, apфведсонит - Arf.

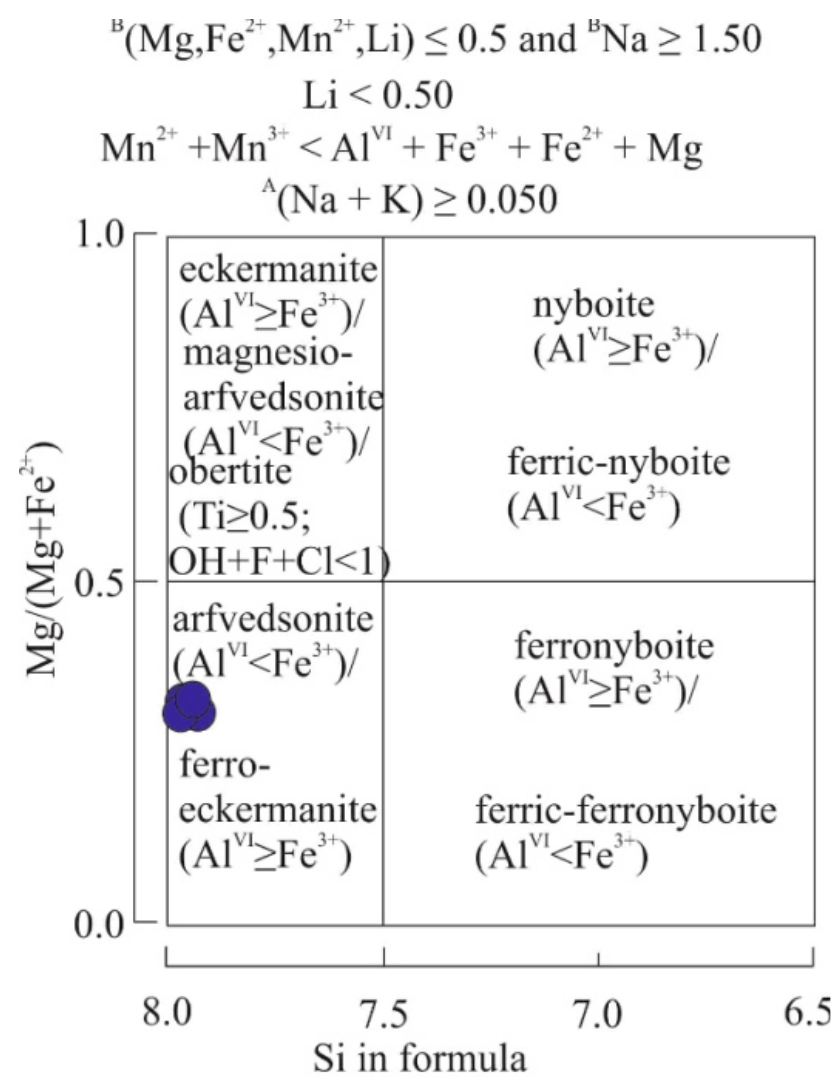

Puc. 3. Классификационная диаграмма для амфиболов [14].

В рудный этап сформировались кварцмолибденитовые и «сухие» молибденитовые прожилки. Мощность их варьирует от долей мм до 1 см, обычно не превышает 3-5 мм. Вкрапленность и агрегатные скопления мелкочешуйчатого молибденита приурочены к зальбандам прожилков, частично в срастании с кварцем. Значительная часть молибденита рассеяна в интерстициях и трещинах пород, обра- зуя обогащенные участки, мощностью от мм до 0,30,5 см. В прожилках присутствуют также более поздние пирит и флюорит, которые обычно рассеяны в жильной матрице.

Мощность «сухих» молибденитовых прожилков обычно не превышает 1-2 мм. Это прямолинейные микропрожилки, встречающиеся в относительно слабонарушенных породах. Кроме того, молибденит распределен в межзерновых пространствах. Кроме молибденита, здесь в небольших количествах присутствуют кварц, пирит, флюорит, тяготеющие к центральной части прожилков.

Квари-сульфидные прожилки завершают рудный этап. Они неправильной формы, мощностью до 2-3 мм (иногда до 0,6-1 см), обычно ветвящиеся. Состав их существенно кварцевый с переменными количествами пирита, флюорита, сфалерита, галенита. В качестве акцессорных минералов присутствуют пирротин, халькопирит, карбонаты.

\section{Заключительный этап}

В этот этап сформировалась алюмофторидная и алюмофосфатная минерализации (5 а, б, д, е). В составе ее установлены: прозопит, ральстонит, геарксутит, жарчихит, черчит и минерал группы плюмбогуммита с промежуточным составом гояцит-горсейкситфлоренсит. С ними ассоциируют кварц, флюорит, барит, сидерит, каолинит, не диагностированный алюмофторид. Минерализация приурочена к центральной части месторождения, где слагает несколько зон прожилкования, вытянутых параллельно дайке гранитов, и прослежена до глубины 500 м, ширина зон достигает десятков метров. Прожилки мощностью до нескольких сантиметров имеют неправильную форму, часто ветвятся, цементируют дробленые граниты. Завершается этот этап аргиллизацией и окварцеванием пород.

Наибольшее распространение получили прозопит, 


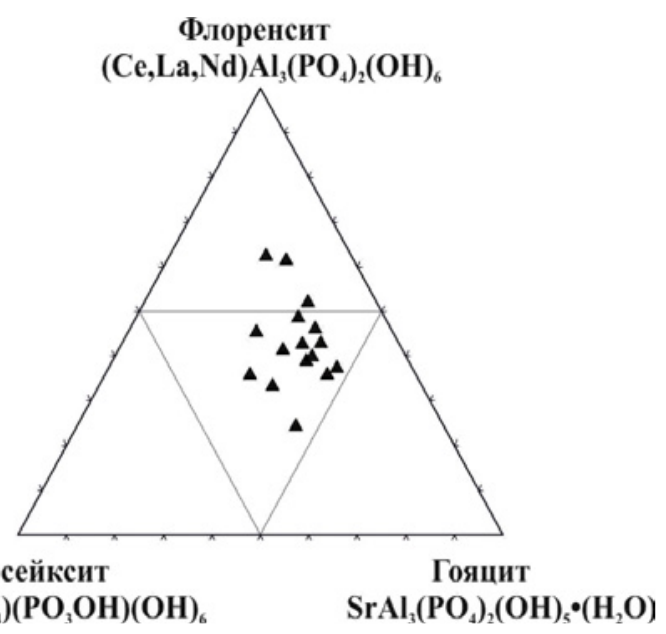

$\mathrm{BaAl}_{3}\left(\mathrm{PO}_{4}\right)\left(\mathrm{PO}_{3} \mathrm{OH}\right)(\mathrm{OH})_{4}$

$\mathrm{SrAl}_{3}\left(\mathrm{PO}_{4}\right)_{2}(\mathrm{OH})_{5} \cdot\left(\mathrm{H}_{2} \mathrm{O}\right)$

Puc. 4. Диаграмма состава (ф.е.) алюмофосфатов из ассоциации с алюмофторидами.

ральстонит, диккит-каолинит, сидерит. Они обычно приурочены к центральной части прожилков, где выполняют интерстиции между зернами кварца и друзовые полости. В меньших количествах присутствует геарксутит, барит, кальцит, флюорит, жарчихит. Химические составы алюмофторидов представлены в таблице 5. Пирит, галенит и сфалерит тяготеют к зальбандам, образуя вкрапленность, гнездообразные скопления, полосовидные выделения. Здесь же присутствуют небольшие количества флюорита.

Прозопит $\left(\mathrm{Ca}_{1,3} \mathrm{Al}_{1,8}\left(\mathrm{~F}_{0,66}, \mathrm{OH}_{0,34}\right)_{8}\right)$ ассоциирует с каолинитом (табл. 5 , рис. 5 б, е). В сравнении с эталонным $\mathrm{CaAl}_{2} \mathrm{~F}_{6}(\mathrm{OH})_{2}$, состоящим на (мас. \%) $16,56 \%$ из $\mathrm{Ca}, 22,29 \%-\mathrm{Al}, 7,44 \%-\mathrm{H}_{2} \mathrm{O}$ и $47,09 \%-\mathrm{F}$, прозопит с Жарчихинского месторождения содержит меньше фтора и больше - воды. В прожилках содержания его колеблются от первых \% до $60 \%$. Он образует гнездообразные скопления радиально-лучистых агрегатов с мелкими друзовидными полостями, выполненными хорошо образованными таблитчатыми и клиновидными кристаллами. Минерал кристаллизовался после кварца, выполнял центральные зоны в прожилках, отлагался в пустотах и трещинках последнего. По трещинам и краям зерен прозопит замещается ральстонитом, геарксутитом, каолинитом. Участками с ним ассоциируют алюмофосфат, черчит, сидерит и недиагностированный алюмофторид.

Ральстонит $\quad\left(\mathrm{Na}_{1,3} \mathrm{Mg}_{0,67} \mathrm{Al}_{1,1}\left(\mathrm{~F}_{5,8}, \mathrm{OH}_{0,2}\right)_{\Sigma=6} \cdot \mathrm{H}_{2} \mathrm{O}\right)$ тесно ассоциирует с прозопитом (табл. 5 , рис. 5д). В отличие от идеализированной формулы эталонного $\mathrm{Na}_{0,7} \mathrm{Mg}_{0,7} \mathrm{Al}_{1,3}\left(\mathrm{~F}_{4,18}(\mathrm{OH})_{1,82}\right)_{\Sigma=6} \cdot \mathrm{H}_{2} \mathrm{O}$ с содержаниями $5,98 \% \mathrm{Na} ; 6,32 \%-\mathrm{Mg} ; 21,06 \%-\mathrm{Al} ; 18,75 \%-\mathrm{H}_{2} \mathrm{O}$ и $39,55 \%$ - F, ральстонит, определенный на Жарчихинском месторождении, отличается лишь большим количеством воды, меньшим алюминия и, в некоторых пробах содержащий до $0,33 \% \mathrm{Ca}$. Количество минерала в прожилках достигает 10-20\%. Он представлен вкрапленностью и гнездами среди прозопита. В пустотах часто встречаются хорошо образованные кристаллы октаэдрического и кубооктаэдрического облика.

Ральстонит кристаллизовался после прозопита, об этом свидетельствует замещение прозопита ральстонитом по краям зерен и трещинкам, а в пустотах кристаллы его нарастают на агрегаты прозопита. Минерал ассоциирует с сидеритом, по отношению к которому является более ранним. Более ранний он также по отношению к недиагностированному алюмофториду. Как и прозопит, ральстонит замещается геарксутитом, каолинитом, недиагностированным алюмофторидом.

Жарчихит с идеализированной формулой $\mathrm{AlF}(\mathrm{OH})_{2}$ был открыт C. В. Болохонцевой с соавторами в 1988 году [12]. Он образует щетковидные агрегаты и мелкозернистые выделения, выполняющие пустоты в кварце. Размер отдельных кристаллов его по удлинению не превышает 2,5 мм. От других алюмофторидов минерал отличается наиболее высоким содержанием Al.

Таблица 5

Химический состав представительных анализов алюмофторидных минералов (мас. \%)

\begin{tabular}{|c|c|c|c|c|c|c|c|c|c|c|c|c|c|}
\hline $\begin{array}{c}\text { Ком- } \\
\text { по- } \\
\text { нент }\end{array}$ & \multicolumn{6}{|c|}{ Прозопит } & \multicolumn{4}{|c|}{ Ральстонит } & \multirow{2}{*}{$\begin{array}{c}\begin{array}{c}\text { Жарчи- } \\
\text { хит* }\end{array} \\
33,73 \\
\end{array}$} & \multicolumn{2}{|c|}{$\begin{array}{c}\text { Недиагности- } \\
\text { рованный } \\
\text { алюмофторид }\end{array}$} \\
\hline $\mathrm{Al}$ & 22,13 & 22,86 & 20,59 & 20,99 & 20,94 & 20,80 & 16,69 & 16,46 & 20,02 & 20,62 & & 25,46 & 23,19 \\
\hline $\mathrm{Ca}$ & 16,16 & 16,09 & 15,83 & 15,94 & 15,70 & 15,81 & 0,33 & 0,31 & - & - & - & - & - \\
\hline $\mathrm{Mg}$ & - & - & - & - & - & - & 7,10 & 7,17 & 6,31 & 5,96 & - & 11,04 & 10,29 \\
\hline $\mathrm{Na}$ & - & - & - & - & - & - & 6,42 & 5,98 & 5,46 & 5,75 & - & 5,16 & 3,08 \\
\hline $\mathrm{F}$ & 25,63 & 27,86 & 24,93 & 24,86 & 24,04 & 24,42 & 35,33 & 35,21 & 38,32 & 38,20 & 23,75 & 40,26 & 48,19 \\
\hline $\mathrm{O}$ & 24,73 & 25,39 & 22,98 & 23,67 & 23,00 & 23,59 & 11,13 & 10,95 & 15,28 & 15,51 & 40,00 & 8,32 & 7,04 \\
\hline Сумма & 88,65 & 92,20 & 84,33 & 85,46 & 83,68 & 84,62 & 77,00 & 76,08 & 85,39 & 86,04 & 97,48 & 90,24 & 91,79 \\
\hline \multicolumn{14}{|c|}{ Кристаллохимические формуль рассчитаны по методу ионно-катионного баланса } \\
\hline $\mathrm{Al}$ & 1,79 & 1,81 & 1,76 & 1,76 & 1,77 & 1,76 & 1,03 & 1,04 & 1,20 & 1,21 & 1,00 & & \\
\hline $\mathrm{Ca}$ & 1,32 & 1,29 & 1,36 & 1,35 & 1,34 & 1,35 & 0,02 & 0,02 & - & - & - & & \\
\hline $\mathrm{Mg}$ & - & - & - & - & - & - & 0,73 & 0,75 & 0,63 & 0,58 & - & & \\
\hline $\mathrm{Na}$ & - & - & - & - & - & - & 1,40 & 1,33 & 1,15 & 1,19 & - & & \\
\hline $\mathrm{F}$ & 0,67 & 0,73 & 0,66 & 0,65 & 0,63 & 0,64 & 5,58 & 5,56 & 6,05 & 6,03 & 1,33 & & \\
\hline $\mathrm{OH}$ & 0,33 & 0,27 & 0,34 & 0,35 & 0,37 & 0,36 & 0,42 & 0,44 & $-0,05$ & $-0,03$ & 1,67 & & \\
\hline
\end{tabular}

Примечание: Состав минералов приведен без учета воды. * - по [12]. 

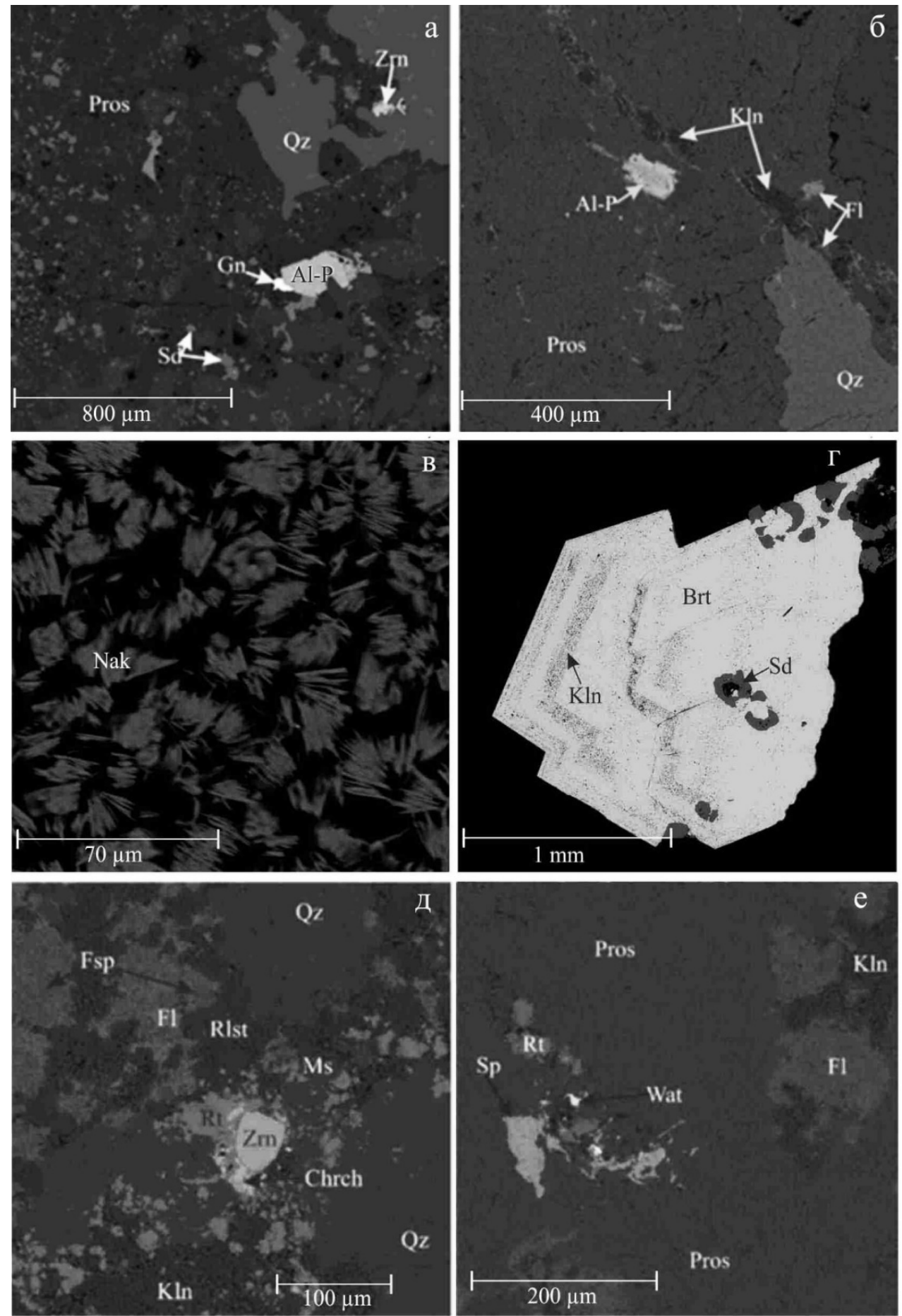

Puc. 5. a, $\sigma$ - зерна алюмофосфата-Al-P в ассоциации с прозопитом-Pros, каолинитом, флюоритом-Fl, сидеритом-Sd, галенитом-Gn, цирконом-Zrn, кварцем; в - форма выделений накрита-Nak; 2 - зональность барита-Brt, зоны серого цвета в барите обусловлены тонкораспыленным каолинитом; $\partial$ - выделение черчита-Chrch в ассоциации с кварцем, ральстонитомRlst, каолинитом, флюоритом, мусковитом-Ms, цирконом, рутилом, калиевым полевом шпатом; $e$ - зерна сфалерита-Sp и ватанабеита-Wat в ассоциации с алюмофторидами, каолинитом, флюоритом и рутилом. Изображения в отраженных электронах.

Геарксутит $\left(\mathrm{CaAl}(\mathrm{OH}, \mathrm{F})_{5} \cdot \mathrm{H}_{2} \mathrm{O}\right)$ совместно с каолинитом является одним из наиболее поздних минералов в кварц-алюмофторидных прожилках. Он образует скопления снежно-белых мелкочешуйчатых агрегатов в пустотах, трещинах, интерстициях, развивается по прозопиту, в меньшей мере по ральстониту.
Недиагностированный алюмофторид содержит в своем составе алюминий, магний, натрий и железо. Встречается в ассоциации с прозопитом, ральстонитом, сидеритом, представлен агрегатами мелких зерен (менее 1 мм) белого цвета, замещающими прозопит, ральстонит. На стенках пустот встречаются мелкие 
кристаллы, представленные комбинацией двух ромбических призм, пирамиды и пинакоида. В составе его, вероятно, присутствует вода. По содержанию главных компонентов он приближается к ральстониту, но кристаллографические формы не позволяют отнести его к последнему.

Минерал группь плюмбогуммита встречен в ассоциации с алюмофторидами (рис. 5 а, б). По химическому составу относится к группе плюмбогуммита, с переменными значениями флоренситового (до $65 \%$ ) и гояцитового (до $60 \%$ ), в меньшей степени горсейкситового (до $45 \%$ ) компонентов (табл. 6, рис. 4). Важной особенностью минерала является относительно высокие концентрации фтора и тория, присутствие железа и кальция.

Химические составы алюмофосфата имеют широкие вариации (рис. 4). При этом значительная часть точек лежит в областях за пределами пятидесятипроцентных границ, которыми обычно ограничены самостоятельные минеральные виды.

Накрит установлен на поверхности агрегатов прозопита и трещинках в кварце в виде радиальнопластинчатых агрегатов и тонкочешуйчатых выделений. Форма выделений показана на рис. 5в. Кристал- лическая структура отличается от каолинита меньшим смещением слоистых пакетов относительно друг друга.

Барит является одним из поздних минералов. Он слагает маломощные прожилки и вкрапленники. В друзовых пустотах встречены его кристаллы. Минерал характеризуется зональным строением (рис. 5г), относительно однородным составом, невысоким содержанием стронция и свинца (до 2 мас. \%). Зональность в барите обусловлена присутствием тонкой вкрапленности каолинита.

Чёрчит встречается в виде мелких зерен (рис. 5 д), тесно ассоциирует с кварцем, ральстонитом и цирконом. Помимо Y, который является основным тяжелым редкоземельным элементом, также наблюдаются переменные количества Gd, Dy, Er, Yb (табл. 7).

Среди алюмофторидов отмечены зерна циркона (рис. 5д), в которых содержится до 1,5 мас.\% гафния и тория.

Сульфидная минерализация в ассоциации с алюмофторидами представлена в основном пиритом, галенитом, сфалеритом. Редко среди них (рис. 5д) встречаются зерна сульфида меди с мышьяком и сурьмой, по составу приближающегося к ватанабеиту $-\mathrm{Cu}_{4}(\mathrm{As}, \mathrm{Sb})_{2} \mathrm{~S}_{5}$.

Таблица 6

Химический состав редкоземельных алюмофосфатов (мас. \%)

\begin{tabular}{|c|c|c|c|c|c|c|c|c|c|c|c|c|c|c|c|}
\hline $\begin{array}{c}\text { Ком } \\
\text { по- } \\
\text { нент } \\
\end{array}$ & 1 & 2 & 3 & 4 & 5 & 6 & 7 & 8 & 9 & 10 & 11 & 12 & 13 & 14 & 15 \\
\hline $\mathrm{Al}_{2} \mathrm{O}_{3}$ & 27,30 & 7,87 & 23,83 & 19,44 & 25,56 & 25,75 & 25,60 & 24,96 & 23,09 & 27,32 & 27,68 & 20,07 & 26,53 & 25,96 & 24,62 \\
\hline $\mathrm{FeO}$ & 3,65 & - & 3,07 & 9,75 & 2,79 & 0,53 & 0,80 & 1,57 & 1,45 & - & 1,30 & 5,80 & - & 2,68 & 3,99 \\
\hline $\mathrm{CaO}$ & 1,18 & 0,85 & 1,72 & 1,86 & 0,97 & 1,25 & 1,41 & 0,81 & 0,87 & - & 0,64 & 1,83 & 0,49 & 1,55 & 0,92 \\
\hline $\mathrm{BaO}$ &, 53 &, 22 & 6,96 & 6,39 & 8,73 & 3,33 & 4,52 & 8,35 & 3,68 & 5,38 & 4,97 & 4,05 & 6,50 & 3,53 & 4,92 \\
\hline $\mathrm{SrO}$ & 6,66 & 20 & 6,11 & 3,58 & 6,27 & 5,00 & 3,25 & 7,60 & 5,71 & 8,70 & 9,61 & 4,77 & 7,99 & 3,87 & 8,33 \\
\hline $\mathrm{Ce}_{2} \mathrm{O}_{3}$ & 5,55 & 6,45 & 6,41 & 4,33 & 4,95 & 7,37 & 8,53 & 3,72 & 6,42 & 8,05 & 5,99 & 6,45 & 6,34 & 8,44 & 5,49 \\
\hline $\mathrm{La}_{2} \mathrm{O}_{3}$ & 3,10 & 2,60 & 2,42 & - & 2,02 & 3,33 & 3,26 & 1,23 & - & 4,40 & 4,26 & 1,22 & 5,18 & 4,05 & 3,83 \\
\hline $\mathrm{Pr}_{2} \mathrm{O}_{3}$ & - & - & 0,92 & - & - & - & 1,24 & - & 1,43 & - & - & - & - & 1,12 & - \\
\hline $\mathrm{Nd}_{2} \mathrm{O}_{3}$ & 1,60 & 2,27 & 2,02 & 2,47 & 2,18 & 1,71 & 3,30 & 1,90 & 3,25 & 2,11 & 1,92 & 3,50 & 0,96 & 1,84 & 1,06 \\
\hline $\mathrm{ThO}_{2}$ & 1,64 & 1,74 & 1,40 & 5,58 & 1,45 & - & 0,92 & 1,59 & 0,80 & 0,76 & 0,82 & 4,68 & - & 1,42 & 1,24 \\
\hline $\mathrm{PbO}$ & - & 3,62 & - & - & - & 4,98 & 3,54 & - & - & - & - & - & - & 3,13 & - \\
\hline $\mathrm{P}_{2} \mathrm{O}_{5}$ & 1,93 & 4,61 & 1,68 & 8,19 & 24,13 & 22,82 & 22,52 & 21,65 & 21,31 & 24,04 & 25,21 & 20,19 & 25,39 & 21,01 & 22,73 \\
\hline Сумма & 84,37 & 84 & 6 & 77 & 84,02 & 78 & 0 & 78,94 & 71,78 & 38 & 86,23 & 76,76 & 0 & 32 & 1,22 \\
\hline$-\mathrm{O}=\mathrm{F}$ & 2,62 & 1,33 & 1,82 & 2,42 & 2,09 & 1,22 & 1,90 & 2,34 & 1,59 & 2 & 01 & $1,1 / 1$ & 1,94 & 1,35 & 1,72 \\
\hline \multicolumn{16}{|c|}{ Кристаллохимические формулы рассчитаны на 14 атомов кислорода } \\
\hline $\mathrm{Al}$ & 4,40 & 2,20 & 4,47 & 3,56 & 4,41 & 5,22 & 4,64 & 4,32 & 4,70 & 4,95 & 4,91 & 4,02 & 4,59 & 5,08 & 4,58 \\
\hline $\mathrm{Fe}$ & 0,42 & 0,21 & 0,41 & 1,27 & 0,34 & 0,08 & 0,10 & 0,19 & 0,21 & - & 0,16 & 0,82 & - & 0,37 & 0,53 \\
\hline $\mathrm{Ca}$ & 0,14 & 07 & 0,20 & & 0,10 & 0,14 & 0,16 & 0,09 & 0,10 & - & 0,06 & 0,23 & 0,05 & 0,18 & 0,10 \\
\hline $\mathrm{Ba}$ & 30 & & & & & & & 0,4 & 0 & 8 & 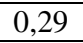 & $\overline{0,2}$ & & 3 & 0,30 \\
\hline $\mathrm{Sr}$ & 53 & & & & & 0,50 & 0,29 & 0,65 & 0,57 & & 0,84 & $0,4]$ & 0,0 & 0,37 & 0,76 \\
\hline $\mathrm{Ce}$ & 0,28 & 0,14 & 0,37 & 0,25 & 0,27 & 0,46 & 0,48 & 0,20 & 0,41 & 0,45 & 0,33 & 0,40 & 0,34 & 0,51 & 0,32 \\
\hline $\mathrm{La}$ & 0,16 & 0,08 & 0,14 & - & 0,11 & 0,21 & 0,18 & 0,07 & - & 0,25 & 0,24 & 0,08 & 0,28 & 0,25 & 0,22 \\
\hline $\operatorname{Pr}$ & - & - & & - & - & - & 0,07 & - & 0,09 & - & - & - & - & 0,07 & - \\
\hline $\mathrm{Nd}$ & 0,08 & 0,04 & 0,11 & 0,14 & 0,11 & 0,11 & 0,18 & 0,10 & 0,20 & 0,12 & 0,10 & 0,21 & 0,05 & 0,11 & 0,06 \\
\hline Th & 0,05 & 0,03 & 0,05 & 0,20 & 0,05 & - & 0,03 & 0,05 & 0,03 & 0,03 & 0,03 & 0,18 & - & 0,05 & 0,04 \\
\hline $\mathrm{Pb}$ & - & - & - & - & - & 0,23 & 0,15 & - & - & - & - & - & - & 0,14 & - \\
\hline $\mathrm{P}$ & 2,54 & 1,27 & 2,92 & 2,39 & 2,99 & 3,33 & 2,93 & 2,69 & 3,12 & 3,13 & 3,21 & 2,90 & 3,15 & 2,95 & 3,04 \\
\hline $\mathrm{F}$ & 2,70 & 1,35 & 2,17 & 2,82 & 2,30 & 1,58 & 2,19 & 2,58 & 2,06 & 1,76 & 1,82 & 2,25 & 2,14 & 1,69 & 2,04 \\
\hline
\end{tabular}

Примечание: Состав минералов приведен без учета воды. В пробе 10 присутствует 1,37 \% $\mathrm{SiO}_{2}$, в 4,8 и 14 около $0,85 \% \mathrm{SO}_{3}$, которые, скорее всего, были захвачены из матрицы. 
Таблица 7

Химический состав черчита (мас. \%)

\begin{tabular}{|c|c|c|c|}
\hline Компонент & 1 & 2 & 3 \\
\hline $\mathrm{Sm}_{2} \mathrm{O}_{3}$ & - & - & 1,33 \\
\hline $\mathrm{Gd}_{2} \mathrm{O}_{3}$ & 1,84 & 2,11 & 3,71 \\
\hline $\mathrm{Dy}_{2} \mathrm{O}_{3}$ & 2,93 & 4,15 & 5,03 \\
\hline $\mathrm{Er}_{2} \mathrm{O}_{3}$ & 1,32 & 1,5 & - \\
\hline $\mathrm{Yb}_{2} \mathrm{O}_{3}$ & 1,58 & 1,61 & 2,49 \\
\hline $\mathrm{Y}_{2} \mathrm{O}_{3}$ & 34,38 & 42,61 & 39,1 \\
\hline $\mathrm{ThO}_{2}$ & - & - & 1,7 \\
\hline $\mathrm{P}_{2} \mathrm{O}_{5}$ & 30,92 & 34,62 & 33,75 \\
\hline $\mathrm{Cyмма}_{2}$ & 72,97 & 86,6 & 88,46 \\
\hline$-\mathrm{O}=\mathrm{F}_{2}$ & - & - & 0,57 \\
\hline $\mathrm{Cумма}$ & 72,97 & 86,6 & 87,68 \\
\hline Кристаллохимические формуль рассчитаньи \\
\hline по методу ионно-катионого баланса \\
\hline $\mathrm{Sm}$ & 0,00 & 0,00 & 0,02 \\
\hline $\mathrm{Gd}$ & 0,03 & 0,03 & 0,05 \\
\hline $\mathrm{Dy}$ & 0,04 & 0,05 & 0,07 \\
\hline $\mathrm{Er}$ & 0,02 & 0,02 & 0,00 \\
\hline $\mathrm{Yb}$ & 0,02 & 0,02 & 0,03 \\
\hline $\mathrm{Y}$ & 0,85 & 0,91 & 0,85 \\
\hline $\mathrm{Th}$ & 0,00 & 0,00 & 0,02 \\
\hline $\mathrm{P}$ & 1,22 & 1,18 & 1,17 \\
\hline $\mathrm{F}$ & 0,00 & 0,00 & 0,07 \\
\hline
\end{tabular}

Примечание: Состав минерала приведен без учета воды.

Таблица 8

Химический состав ватанабеита (мас. \%)

\begin{tabular}{|c|c|c|}
\hline$№$ п/п & $1^{*}$ & 2 \\
\hline $\mathrm{Fe}$ & 0,54 & - \\
\hline $\mathrm{Cu}$ & 34,68 & 41,1 \\
\hline $\mathrm{Zn}$ & 6,93 & - \\
\hline $\mathrm{Sb}$ & 21,89 & 14,3 \\
\hline $\mathrm{As}$ & 3,9 & 15,4 \\
\hline $\mathrm{S}$ & 24,04 & 26,2 \\
\hline $\mathrm{Ag}$ & - & 0,1 \\
\hline $\mathrm{Mn}$ & - & 0,3 \\
\hline $\mathrm{Bi}$ & - & 2,4 \\
\hline $\mathrm{Cумма}$ & 91,98 & 99,8 \\
\hline Кристаллохимические формульи рассчитаньи \\
\hline по методу ионно-катионного баланса \\
\hline $\mathrm{Fe}$ & 0,06 & 0,00 \\
\hline $\mathrm{Cu}$ & 3,64 & 3,96 \\
\hline $\mathrm{Zn}$ & 0,71 & 0,00 \\
\hline $\mathrm{Sb}$ & 1,20 & 0,72 \\
\hline $\mathrm{As}$ & 0,35 & 1,26 \\
\hline $\mathrm{S}$ & 5,00 & 5,00 \\
\hline $\mathrm{Ag}$ & 0,00 & 0,01 \\
\hline $\mathrm{Mn}$ & 0,00 & 0,03 \\
\hline $\mathrm{Bi}$ & 0,00 & 0,07 \\
\hline
\end{tabular}

Примечание: * - минерал с Жарчихинского месторождения.

В сравнении с эталонным ватанабеитом [15] (табл. 8), в нем (проба $1 *$ ) ниже содержание $\mathrm{Cu}$, существенно более низкие концентрации Аs и высокие $\mathrm{Zn}$.

Карбонаты встречены на участках метасоматически замещенных пород, где слагают редкие карбонатные и кварц-карбонатные прожилки, сформировавшиеся после молибденитовых, флюоритовых и сульфидных прожилков, а также в ассоциации с алюмо- фторидными минералами. Среди карбонатов диагностированы кальцит, анкерит, сидерит.

Сидерит присутствует в алюмофторидных прожилках, где образует вкрапленность, гнезда, а в друзовых пустотках присутствуют ромбоэдрические кристаллы. В последних случаях сидерит тесно ассоциирует с ральстонитом. Для минерала характерна неоднородность состава, связанная с широкими вариациями (от 1 до 10 мас. \%) концентраций марганца. Содержания других компонентов не превышают сотых долей процента.

Мономинеральные карбонатные прожилки завершают этот этап, по своему составу они делятся на кальцитовые и анкеритовые. Как правило, мощность их варьирует от долей мм до 5-7 см.

\section{Обсуждение результатов}

Результаты проведенных исследований указывают на сложное многоэтапное развитие молибденового месторождения Жарчиха. В составе месторождения, наряду с трубообразным рудным телом, встречаются «линейные» жильные или жилоподобные тела и пострудные дайки. При этом отмечается наличие разновозрастной фтор-бериллиевой, кварц-молибденитовой, алюмофторидной и карбонатной минеральных ассоциаций.

Анализ многочисленных публикаций по минералогии молибденовых месторождений как зарубежных $[3,4,5]$, так и отечественных $[1,2,9,11,13]$, показал, что фтор-бериллиевая [16] и алюмофторидная (алюмофосфатная) минерализации не являются типоморфными. Поэтому присутствие их на Жарчихинском месторождении представляет большой интерес. Подобную минерализацию можно выделить в специфический минеральный тип, либо же, при отсутствии генетической связи между этими типами, связывать такую ассоциацию с телескопированием разновозрастных парагенезисов.

Фтор-бериллиевая минерализация Жарчихинского месторождения расположена автономно от молибденовой. По своим минеральным и геохимическим свойствам она идентична с распространенным в регионе флюорит-фенакит-бертрандитовым оруденением и находится в пределах Западно-Забайкальской бериллиеносной провинции [6], специализированной на флюорит-бертрандит-фенакитовую минерализацию, имеющую возраст 224-226 млн лет [7].

Алюмофторидная минерализация, как известно, является типоморфной для щелочных комплексов пород. Проведенные минералогические исследования выявили, что алюмофторидная минерализация оторвана от основного рудного этапа и пространственно ассоциирована с кварцевыми прожилками.

Исследования выполнены при финансовой поддержке РФФИ 17-05-00129_а. 


\section{ЛИТЕРАТУРА}

1. Покалов, В. Т. Рудно-Магматические системы гидротермальных месторождений / В. Т. Покалов // Недра. - М., 1992. - $177 \mathrm{c}$.

2. Батурина, E. E. Молибденовые и вольфрамовые месторождения Западного Забайкалья (основные черты металлогении и геохимии) / Е. Е. Батурина, Г. С. Рипп // Наука. M., $-1984 .-152$ c.

3. Processes and ore genesis at the Yaochong Mo deposit, Henan Province, China / Q.-Q. Liu [et al.] // Ore Geology Reviews - 2017. - V. 86. - P. 692-706.

4. Metallogenic age and hydrothermal evolution of the Jidetun Mo deposit in central Jilin Province, northeast China: Evidence from fluid inclusions, isotope systematics, and geochronology / Z.-G. Wang [et al.] // Ore Geology Reviews - 2016. - V. 89. P. 731-751.

5. Shrimp U-Pb, Ar-Ar and fission-track geochronology of W-Mo deposits in the Balkhash Metallogenic Belt (Kazakhstan), Central Asia, and the geological implications / X. Chen [et al.] // Journal of Asian Earth Sciences. - 2015. - V. 110. - P. 19-32

6. Куприянова, И. И. Бериллиевые месторождения России / И. И. Куприянова, Е. П. Шпанов // ГЕОС - М. - 2011. - 354 с. 7. Возраст рудоносного магматизма Ауникского месторождения Западно-Забайкальской бериллиеносной металлогенической провинции / Д. А. Лыхин [и др.] // Доклады PAH. - 2003. - T. 392. - № 2. - C. 230-234.

8. Канакин, С. В. Алгоритм учета фона в рентгеноспектральном микроанализе с волновой дисперсией / С. В Канакин, Н. С. Карманов, М. И. Лапина // Тез. докл. III Всероссийской и VI Сибирской конф. по рентгеноспектрально-

Геологический институт СО РАН, г. Улан-Удэ

Савченко Алена Алексеевна, аспирант

E-mail: savchenko.alena.alex@rambler.ru

Тел.: 8-(3012)-43-39-55; 8-(983)-536-19-87

Рипп Герман Самуилович, к.г.-м.н., ведущиий научный сотрудник

E-mail: ripp@ginst.ru

Тел.: 8-(3012) 43-39-55 му анализу. - Иркутск. - 1998. - 66 с.

9. Верник, В. П. Жарчихинское молибденовое месторождение. В кн. Месторождения Забайкалья / В. П. Верник, Г. С. Рипп // Б.и. - Чита.- 1995. - Т.1. - Кн.1. - С. 176-179.

10. Объяснительная записка листа M-48-VI, серия селенгинская // Министерство природных ресурсов России / В. С. Платов [и др.] // ВСЕГЕИ (Санкт-Петербург). - Москва. 2000. - $156 \mathrm{c}$

11. Покалов, В. Т. Жарчихинское проявление молибдена в брекчиевой трубке в каледонидах Западного Забайкалья / В. Т. Покалов, С. В. Болохонцева, В. В. Васин // Известия. Сер. геологическая. - М. - 1985. - №7. - С. 99-107

12. Жарчихит $\operatorname{AIF}(\mathrm{OH})_{2}-$ новый минерал / С. В. Болохонцева [и др.] // Записки всесоюзного минералогического общества. - 1988. - Вып.1. - С. 79-83.

13. Новая вулканическая структура с молибденовой минерализацией в Западном Забайкалье / В. В. Скрипкина [и др.] // Доклады АНСССР. - 1982. - Т.264. - №6. - С. 1461-1464. 14. Nomenclature of amphiboles: Additions and revisions to the International Mineralogical. Associations amphibole nomenclature / B. E. Leake [et al.] // American Mineralogist. - 2004. - V. 89. - P. 883-887.

15. Watanabeite, $\mathrm{Cu}_{4}(\mathrm{As}, \mathrm{Sb})_{2} \mathrm{~S}_{5}$, a new mineral from the Teine mine, Sapporo, Hokkaido, Japan / M. Shimizu [et al.] // Mineralogical Magazine. - 1993. - V. 57. - P. 643-649.

16. Проблема источников флюидов Оротского бериллиевого месторождения (Западное Забайкалье) / М. О. Рампилов [и др.] // Известия Сибирского отделения. Секции наук о Земле Российской академии естественных наук. Геология, разведка и разработка месторождений полезных ископаемых. - 2017. - Т. 40. - № 1. - С. 42-51.

Geological Institute SB RAS, Ulan-Ude

Savchenko A. A., post-graduate student, laboratory assistant E-mail: savchenko.alena.alex@ rambler.ru Tel.: 8-(3012)-43-39-55; 8-(983)-536-19-87

Ripp G. S., PhD, leading researcher

E-mail: ripp@ginst.ru

Tel.: 8-(3012) 43-39-55 